\title{
PREDICTORS OF PUBLIC SCHOOL LEADERSHIP CAPACITY IN BISHKEK
}

\author{
Swetal Sindhvad ${ }^{1}$ \\ isDevelopment, USA
}

Jayson W. Richardson

University of Kentucky, USA

\author{
Alexandr Ivanov \\ Foundation for Education Initiatives Support, Krygyzstan
}

John Eric M. Lingat

University of Kentucky, USA

\begin{abstract}
The purpose of this study was to provide insight into contextual factors predicting the extent of principals' sense of self-efficacy, or capacity, for instructional leadership, school management, and parent engagement in public schools in the city of Bishkek following Kyrgyzstan's decentralization reforms post-independence. Findings indicate three contextual factors influencing principals' capacity that deserve attention in developing school leadership training: (i) principals' sense of job satisfaction; (ii) their perception of the effectiveness of instructional supports in improving student learning; and (iii) teacher capacity for maintaining communication with parents. Findings pointed to the significance of the emerging elitization of public schools in Bishkek, and parental pressures for extra-curricular, enrichment to promote student-centered learning that influence school leadership. The study expands the literature on school leadership in the context of decentralization, particularly in post-Soviet countries.
\end{abstract}

Keywords: Instructional Leadership; Principals; Leadership Training; Decentralization; Asian Studies

\footnotetext{
${ }^{1}$ Correspondence: ssindhvad@i3development.org
} 


\section{Introduction}

In many developing countries, it is believed that experience, measured by years of teaching, is sufficient to take on the roles and responsibilities of a school leader (Bush, 2018). Policies toward decentralization of education systems complicate this belief. While there is a considerable difference in the form decentralization takes within each country's context, there are common challenges that school-level management face while taking on responsibilities inherited by central-level administration and the increasing pressures for improved student achievement. As such, professional development for these school leaders often follows a onesize-fits-all approach that does not take into consideration contextual factors affecting principals' decision-making processes, particularly in terms of instructional leadership. Research indicates a positive relationship between principals' sense of self-efficacy and their instructional leadership, which professional development programs can foster (Bush, 2018; Hallinger et al., 2018). The purpose of the current study is to provide insight into the contextual factors predicting the extent of principals' sense of self-efficacy, or capacity, for instructional leadership, school management, and parent engagement in public schools in the city of Bishkek following Kyrgyzstan's decentralization reforms post-independence.

It is commonly perceived that school principals' central responsibility is school management, which involves determining staffing needs, scheduling classes, ordering textbooks and instructional materials, and maintaining records required by the central Ministry of Education. Following decentralization reforms, school principals are likely to have added areas of responsibility including: instructional supervision, school-community relationships, and school-ministry communications. Among these new responsibilities, instructional supervision is most closely linked to teacher and student outcomes. However, instructional supervision is the least likely to be focused on by school principals (Chapman, 2000). Instructional supervision is central to instructional leadership. The following literature review provides an overview of instructional leadership, principal self-efficacy, and the context of the current study.

\section{Instructional Leadership}

Instructional leadership is characterized by a school leader's efforts of developing a vision, mission, school culture, and climate that have a strong focus on instructional improvement. Activities that support these tasks include supporting teachers' classroom instruction through mentoring, providing professional development, supplying pedagogically sound classroom resources, and maintaining relationships with parents about teaching and learning (Bamburg \& Andrews, 1990; Bush, 2014). While instructional leadership has its roots in the United States, many countries with newly adopted education policies, apply it in terms of job qualifications, selection criteria, training programs, and principal evaluation standards (Hallinger et al., 2018).

There are barriers to the full realization of the potential for instructional leadership for developing countries transitioning to a decentralized system. These include principals' limited autonomy, continued focus on routine management, and a lack of involvement in curriculum and instruction due to the remnants of centralized decision-making processes. Evidence of principals enacting instructional leadership in developing countries is rare and often limited to exceptions rather than the rule (Oplatka, 2004). Sentocnik and Rupar (2009) discussed that while legislation in post-Soviet Slovenia explicated the role of the principal as an instructional leader, instructional goals were lost in day to day preoccupations with administrative tasks. The authors found that many principals feel they do not have the time to fulfill all their new responsibilities. 
Additionally, these principals tend to prioritize managerial and financial tasks over instructional responsibilities. Along with a lack of time, many principals who are engaged in decentralization efforts indicate that they have insufficient knowledge and skills to oversee improvements in teacher instruction (Koren, 2007; Rupar, 2008 as cited in Sentocnik \& Rupar 2009). Yakavets (2016) discussed the challenges of post-Soviet transition experienced in Kazakhstan in terms of the pressure of bureaucratic oversight and regulations placed on principals and their teachers. Yakavets highlighted the enormous amount of time Kazakh school leaders spend on administrative issues and the serious consequences for a school if there is evidence of poor performance in this area. Yakavets found that Kazakh school principals are more of an extension of the local administration than members of the teaching staff.

\section{Principal Self-Efficacy}

A significant body of research conducted in the 2000 s reveals a positive relationship between principal self-efficacy, instructional leadership, and teacher attitudes and behaviors (Hallinger et al., 2018). A principal's sense of self-efficacy is a judgment of their capacity to structure a particular course of action in order to produce desired outcomes in their school (Bandura, 1997). The construct of self-efficacy is composed of personal self-efficacy and outcome expectancy, or one's estimate that a given behavior will lead to certain outcomes. Behavior is often predicted through the examination of both self-efficacy and outcome expectancy beliefs (Bandura 1977, 1982).

In a study of instructional leadership among primary school principals in Iran, Hallinger et al. (2018) found that principal self-efficacy, instructional leadership, and teacher self-efficacy evidenced moderately strong, statistically significant, positive relationship with each other as well as with teacher commitment. The authors concluded that principals with stronger self-efficacy were perceived by their teachers to exercise the role of instructional leader more actively than those with a lower sense of self-efficacy. A principal's core values and beliefs about their ability to provide quality education shapes their leadership practices (Hallinger et al., 2018).

Self-efficacy and outcome expectancy are differentiated because a principal can believe that a particular course of action will produce certain outcomes, but if they have doubts about whether they can perform the necessary activities, then such information does not influence their behavior (Bandura, 1977). Bandura's (1997) theory of triadic reciprocal causation is the rationale explaining the relationship between principal self-efficacy and their performance, use of power, and coping strategies. Triadic reciprocal causation focuses attention on the interaction between internal and external factors, or personal characteristics, and behavioral and environmental factors, that at work in a leadership context. Principals' behavior is influenced by their internal thoughts and beliefs. Beliefs are shaped by environmental elements,including other individuals, (Sindhvad, 2009).

The existing literature body contains a small subset of studies that examine the interaction between and among factors that predict principal behavior. For example, Federici et al. (2012) found that principal self-efficacy and their sense of job autonomy were positively related to job satisfaction and negatively related to contextual constraints such as financial and administrative limitations or those set by the municipal authority. The authors concluded that principals with a high level of self-efficacy and a large degree of control and latitude over their work are likely to be more satisfied with their job. This is likely to reduce job stress and is associated with overcoming environmental obstacles. Additionally, DeMoulin (1992) found school level to be factor that influenced principal self-efficacy. DeMoulin explored the 
relationships among motivation, confidence, and stress as predictors of principal's perceived self-efficacy. Significant differences were found in levels of self-efficacy between elementary school and middle school principals and between elementary school and high school principals. No significant differences were reported between middle school and high school principals.

Smith et al. (2006) studied the influence of school and principal demographic variables on principals' sense of self-efficacy for instructional leadership and management. The demographic variables investigated were principal's race, gender, years in education, years as a principal at a particular school, total years as a principal, academic degree of the principal, number of students enrolled at principal's school, percent of students on free/reduced lunch, and location of the school. The authors found that the amount of reported time devoted to management was lower for principals with more experience, and the amount of reported time devoted to instructional leadership was higher for females and principals working in schools with a higher proportion of students receiving free/reduced lunch.

Few studies in the existing literature body focus on the above interactions in the context of developing countries following decentralization reforms to predict principal behavior. Chapman and Burchfield (1994) found that headmasters in Botswana, who were pessimistic about the efficacy of their supervisory and management efforts, lacked confidence in their ability to help teachers improve their teaching and in their ability to get help from the Ministry of Education. The authors concluded that leadership training needs to focus on helping headmasters in newly decentralized contexts better understand instructional supports such as instructional supervision and other direct and indirect actions on their part that would most likely raise student performance. Training that aims to shape self-efficacy must ensure that leaders have the skills necessary to act in the desired ways and an gain a better understanding of the links between the behaviors and the desired achievement outcome. Either factor alone is insufficient. However, while skill acquisition involves only new learning, efforts to increase leaders' understanding of the efficacy of various practices often involve undoing prior learning, which is based on accumulated experience and interpretation of the operating dynamics of the school (Chapman \& Burchfield, 1994).

DeJaeghere, Williams, and Kyeyune (2008) assessed the efficacy of secondary school headteachers in Uganda in the areas of leadership, management, instructional supervision, and community relations. Findings from this study suggest the need for designing training that targets gaps in specific skill domains and to give attention to the differing roles and responsibilities of head and deputy headteachers, the school size and resources, gender, and the location of the population that the school serves. The authors concluded that training for these leaders should be contextualized and targeted.

Sindhvad (2009) investigated factors predicting a sense of self-efficacy for instructional leadership and school management among principals in the Philippines. The author focused on factors predicting principals' perceived effectiveness for instructional supports. The researcher found that principal self-efficacy for instructional leadership was dependent on how effective they believed instructional supports were to support student learning, their level of control over them, their time spent on instructional leadership tasks, and their level of job satisfaction. The researcher indicated that there is a need for instructional leadership training to include opportunity for mastery experiences in implementing strategies aside from classroom resources that support the teaching-learning process.

The current study is informed by the findings of this small subset of studies and uses the study by Sindhvad (2009) in an effort to broaden the literature by investigating the 
interaction between internal and external factors to predict principal behavior in the postSoviet context of Bishkek, Kyrgyzstan. The following section describes education management in Kyrgyzstan, provides details on education in Bishkek, and lays out the need for instructional leadership in promoting student-centered classroom instruction in Kyrgyz schools.

\section{Kyrgyz Education System}

Before independence in 1991, the former Soviet Union led the Kyrgyz education system. Primary and secondary education was largely delivered through Moscow-directed public schools. The former Soviet Union identified education as a high priority sector. Therefore, public schools were well-resourced, education participation levels were relatively high, and teachers and school principals enjoyed a stable job as well as a respected social status.

Education was free at all levels and compulsory through Grade 10. However, teaching was teacher-centered and emphasized skill repetition with very limited opportunities for students to question and apply concepts. Teachers followed instructional methods prescribed by the state. School principals worked to manage and maintain school facilities. Diversion from state prescribed teaching and content was rare due to three levers: strict control, teachers' general incapacity to work independently, and a lack of general teaching resources. Student learning was limited due to a lack of involvement of the school principal, teachers, and stakeholders such as parents in decision-making processes (Akmatova 2008; Mertaugh 2004).

\section{Decentralization}

One of the first acts as the newly independent republic, Kyrgyzstan decentralized responsibility for finance and provision of primary and secondary education to the local government. This action was in response to recommendations from international development agencies as an effort to correct shortcomings in budgetary management and governance arrangements that led to inefficiencies in education spending (Mertaugh, 2004). School ownership thus was transferred to regional and local governments. This transfer also included the responsibility for financing and maintaining these schools. Full responsibility for school management was passed on to the school principal. The strict hierarchical power structure of the Soviet regime limited the responsibilities of the school principal. Following decentralization reforms, however, the school principal was often unprepared for a widening of responsibilities due to the limited scope under which she performed before independence.

In their analysis of strategies employed by governments of post-Soviet countries (including Kyrgyzstan), Chapman et al. (2005) found that the shift in responsibilities to school principals was not supported with any training for school principals. One reason for failure to provide training was that under the Soviet Union, the nature of school principal preparation was determined in Moscow. McLean and Karimov (2004) identified the absence of available models for education management as a barrier to effective school leadership in Kyrgyzstan. Therefore, various models of school leadership enabling the development of a professional culture for educational management have been missing in the country. McLean and Karimov stated that how a school principal manages is based on stereotypes, what they have seen, and nonsystematic formation of their practices.

To date, decentralization in the country has occurred at a minimum. Central government mandates of class sizes and teaching loads constrain regional and local governments' management discretion. Lack of revenue of regional and local governments to 
cover school operating costs requires the central government to exercise authority. In order to keep schools in operation, teacher salaries (and sometimes utilities) are financed by state budgets. Other inputs (including textbooks) are financed by parents or the local community which involves the school principal building stakeholder relationship This is a new role for the school leader. Nevertheless, these school principals lack the knowledge and skills to engage parents and community members in school decisions (Open Society Institute, 2002).

\section{City of Bishkek}

The capital city of Bishkek is an outlier following decentralization reforms because it is the only region in the country that receives substantial funding from municipal taxes to finance schools. Bishkek has a higher level of school autonomy and broader stakeholder participation in school budget allocation. One-third of Bishkek school budgets are financed by parental contributions. Following school autonomy and stakeholder participation, Bishkek is subject to greater transparency of school management (Herczynski, 2002).

\section{Student-Centered Learning}

Along with offering advice to decentralize authority, international development agencies pushed for policy reforms following Western education values such as studentcentered learning. A study by Prince-Rom and Sainazarov (2010) found that Krygyz teachers focus on getting students to think independently though their interpretation of studentcentered learning or active learning methods varied greatly. Researchers identified a range of constraints that prevented teachers from fostering student-centered learning. These include a lack of teacher guides that specify how to integrate active-learning methods, increased teaching loads, lack of support from school principals in applying active-learning methods, and criticism over student overcomes by regional administration during inspections. De la Sablonniere (2009) argued that the biggest challenge facing the educational system in Kyrgyzstan, as in the rest of Central Asia, is the lack of a normative structure in the educational system promoting student-centered teaching. The author argued that more resources need to be provided to the minority who are championing student-centered teaching.

Kyrgyzstan still faces major challenges in developing its education system to be in line with a new value system and changing social policies and structures. Substantial improvements in the outcomes of education have yet to be realized. This is evident in the results of the 2006 and 2009 cycles of the Program for International Student Assessment (PISA) where Kyrgyzstan ranked last in math, science, and reading among participating nations. As a response, the government's Education Development Strategy of the Kyrgyz Republic for 2012-2020 prioritized a competency-based approach and a student-centered pedagogy. Implementation of this strategy relies on school principals serving as instructional leaders whose job it is to improve teaching and learning.

The literature review above highlights that instructional leadership is rare in most developing countries generally, and post-Soviet countries specifically, due to barriers and constraints inherited by authoritative systems. Given the context of Kyrgyzstan, and particularly Bishkek, it is likely that instructional leadership is not in full form. Since principals were limited to school management during the Soviet regime, it is expected that their sense of self-efficacy for management is higher than it is for instructional leadership. A sense of self-efficacy is also likely to be higher for stakeholder engagement, given the influx of parent contributions in Bishkek. Despite a lack of training in stakeholder engagement techniques, it is likely that principals have 'learned the ropes' based on stereotypes, what they 
have seen, and nonsystematic formation of practices. It is also expected that principals' sense of outcome expectancy for instructional supports is likely to be higher for traditional inputs such as classroom resources and learning aids since principals are likely to have experience working with them during the Soviet era. The need for parental engagement to supplement school budgets and to meet the administrative demands of the local authority is likely to add pressure on these principals.

\section{Methods}

Self-efficacy is a latent trait that is not directly measured but rather estimated through tools such as survey items (Cheema, 2013). Usher (2009) suggests that qualitative methods such as semi-structured interviews allow for the examination of how people think and how they come to develop the perspectives they hold, which contribute to their sense of efficacy. Usher and Pajares (2008) discussed that investigation of self-efficacy beliefs and factors influencing them is situated in Bandura's theory of self-efficacy beliefs constituting the key factor of human agency. For that matter, a mixed-methods approach was used to study selfefficacy of Bishkek school principals. The following research questions guided the study: (1) To what extent do Bishkek public school principals believe they have the capacity for school management, instructional leadership, and stakeholder engagement? (principal capacity); and (2) To what extent do Bishkek public school principals believe that instructional supports lead to improved student-centered learning? (effectiveness of instructional supports).

The survey used was adopted from Sindhvad (2009), which was informed by the work of Kemmerer (1991) and Tschannen-Moran and Hoy (2001). The survey was designed according to strategies employed by Tschannen-Moran and Hoy (2001) to capture the context-specific nature of principals' perceived capacity and principals' perceived effectiveness. For this study, modifications were made to reflect the scope of school principal responsibilities for engagement with parents and local authority. The scales were constructed according to the framework for teacher incentives as detailed by Kremmerer (1990) who found that non-financial incentives for improved teacher performance included instructional materials available in the classroom, instructional supervision, and training.

The survey consisted of a 19-item scale to measure principal capacity and a 10-item scale to measure the effectiveness of instructional supports (Table 1). Factor analysis of the 19 items composing the principal capacity scale yielded three factors with eigenvalues above .1: 1.) school management (items 1-5), 2.) instructional leadership (items 6-16) and 3.) parent engagement (items 17-19). Cronbach's alpha statistics indicated that data collected on principal capacity $(\alpha=.878)$ and effectiveness of instructional supports $(\alpha=.814)$ had acceptable internal consistency.

The survey also included items measuring perceptions on teacher capacity, as well as a scale measuring time on instructional leadership and management tasks, and self-rating on effectiveness as a school principal and job satisfaction. Demographic data collected through the survey included the type of public school, curriculum followed, percentage of disadvantaged poor students, highest level of education attained, years of teaching experience, years of school principal experience, age, and gender. Descriptive statistical analyses were conducted to identify key characteristics among the principals in the sample.

A partner organization, the Foundation for Education Initiatives Support (FEIS), along with city-level education authorities in Bishkek, supported contextualization, translation, and dissemination of the survey. Upon gaining permission from the Bishkek City Department of Education to conduct the survey, FEIS requested via email participation from all principals of public general education schools $(n=102)$ in Bishkek. A link to complete and 
submit the survey online was included in the email. A total of 81 principals responded to the online survey for a return rate of $79 \%$.

\section{Table 1.}

Principal Self-Efficacy and Outcome Expectancy Scale Items

\section{Principal Capacity}

In your current role as principal, to what extent can you...

1. Make textbooks available in time for start of school year

2. Provide teacher guides to teachers

3. Make basic resources available in classroom. (notebooks, writing tools, chalkboard, etc.)

4. Make technology resources available in the classroom (laptops, iPads, educational software, printers, whiteboard, etc.)

5. Make learning aids available. (globes, maps, posters, science lab equipment, etc.)

6. Mentor teachers in making decisions about the best teaching method

7. Mentor teachers to make decisions about methods for assessing student learning

8. Analyze classroom practices

9. Conduct teacher performance assessment

10. Provide teachers constructive feedback on teaching performance

11. Mentor teachers to use learning aids to enhance student learning

12. Mentor teachers to make effective use of instructional time

13. Provide teachers the opportunity to learn about teaching strategies for active learning

14. Provide teachers the opportunity to understand student-centered learning

15. Provide teachers the opportunity to develop skills and knowledge to teach different subjects

16. Provide teachers the opportunity to learn classroom management strategies

17. Provide parents and other community members with information about school performance

18. Provide parents with information about student achievement

19. Provide parents with opportunities to visit their child's classroom

\section{Effectiveness of Instructional Supports}

To what extent do the following influence student learning?

1. Classroom resources (computer, laptop, books, etc.)

2. Learning aids (globes, maps, posters, science lab equipment, etc.)

3. New teaching methods

4. Your feedback from classroom observations

5. Mentoring teachers

6. Training / professional development

7. Parent involvement at school

8. Other family member involvement at school

9. Community attention on student achievement

10. City Department of Education involvement

Note. Scale: $6=$ Great Deal; $5=$ Quite a Bit; $4=$ Some Influence; $3=$ Little; $2=$ Very Little; $1=$ None

To better understand the quantitative results, qualitative data were collected. Interviews were conducted to inform principals' preparation for and practice of instructional leadership supporting student-centered teaching in their schools. FEIS randomly selected 
five principals to be interviewed. Interviews were semi-structured and included questions about how student-centered learning took place in their schools, the role of the principal in supporting teachers to foster student-centered learning, and their perception of how training and professional development has prepared them for their role as principal. Responses were translated into English. Thematic analysis of the interview data was conducted to provide a narrative triangulation of the quantitative findings.

Linear regression measures the extent of a linear relationship between variables by predicting the value of the dependent variable based on the value of one or more independent variables. Therefore, any change in an independent variable will produce a corresponding change in the dependent variable. Linear regressions were conducted to predict factors contributing to principals' sense of capacity and their sense of effectiveness for instructional supports (EIS) in order to determine a predictive model of school leadership for Bishkek public schools. Principals received capacity scores (i.e., average rating) for each of the following three factors: school management, instructional leadership, and stakeholder engagement. The scores were the dependent variables in linear regression analysis conducted to predict principals perceived self-efficacy, or capacity, for the three areas. Each respondent was given a score for EIS calculated by taking the average rating of items measuring principals' perceived effectiveness of instructional supports. This score was the dependent variable in the regression conducted to predict EIS.

\section{Data Analysis Rationale}

Hallinger and Heck (1996) found that principals can influence student achievement when efforts are aimed toward influencing internal school processes. Doing this requires a level of self-efficacy. A principal's sense of self-efficacy is a judgment of one's capacity to structure a course of action in order to produce the desired outcome (Bandura, 1997). Outcome expectancy is a principal's estimate that their actions will lead to desired schoolbased outcomes (Bandura, 1982). Efficacy and outcome expectations are differentiated because individuals can believe that a particular course of action will produce certain outcomes, but if they have doubts about whether they can perform those activities, then there may be no impact on their behavior (Bandura, 1977). Self-efficacy and outcome expectancy, therefore, affect the development and skillful execution of functional leadership strategies (McCormick, 2001). Bandura's (1997) theory of triadic reciprocal causation applies to this study in that there is a perceived relationship between principals' sense of efficacy and their performance.

Given this understanding of the literature, the survey was designed to measure principals' perceived capacity and principals' perceived effectiveness operationalizing the constructs of personal self-efficacy and outcome expectancy, respectively. Analysis linked the self-ratings of principals' beliefs and values as potential predictors of their leadership practices.

\section{Quantitative Results}

Of the 81 principals who participated in this study, $84 \%$ were female, and $16 \%$ were male. The majority of principals (96\%) were above 40 years of age, attained highest level of education at the specialist level ( 5 years of study at a university), had more than 16 years of teaching experience, and were working in schools serving between 20-29\% of the student body that identified as disadvantaged poor. Levels of experience as school principal varied with $32 \%$ of principals reported more than 16 years of experience, $27 \%$ reported $6-10$ years, 
and $26 \%$ reported less than 5 years. Seventy-five percent of principals reported being 'somewhat effective' as a school principal and 70\% reported they felt satisfied in their jobs.

Survey responses were positively skewed for instructional leadership $(\mathrm{M}=4.6$; $\mathrm{SD}=$ $.93)$ and parent engagement $(\mathrm{M}=4.9 ; \mathrm{SD}=1.0)$, and symmetrically distributed for school management $(\mathrm{M}=4.2$; $\mathrm{SD}=1.2)$. Principals rated themselves as having quite a bit of influence over responsibilities of instructional leadership and parent engagement. Principals rated themselves as having 'some influence' over responsibilities under school management. The coefficients of variation for the dependent variables reveal that principals' beliefs vary more in their capacity for school management $\left(s^{2}=29.3\right)$, compared with capacity for instructional leadership $\left(s^{2}=20.4\right)$ and capacity for parent engagement $\left(s^{2}=20.7\right)$.

Frequency data indicate that principals rated themselves as having a great deal of influence over each of the responsibilities under parent engagement including provide parents with opportunities to meet their students' teachers (41\%), provide parents with information about student achievement (35\%), and provide parents and other community members with information about school performance (31\%).

As detailed in Table 2 , results of the regression analysis predicting principal capacity for school management yielded an $\mathrm{F}$ of $6.138(p<.05)$ and an $\mathrm{R}$ of .609. The analysis explained $37 \%$ of the variation in principals' perceived capacity for tasks such as providing technology and learning aids in the classroom. Results of the regression analysis predicting principal capacity for instructional leadership yielded an $\mathrm{F}$ of $8.497(p<.05)$ and an $\mathrm{R}$ of .670. The analysis explained $45 \%$ of the variation in principals' perceived capacity for instructional leadership. Results of the regression analysis predicting principal capacity for parent engagement yielded an $\mathrm{F}$ of $6.309(p<.05)$ and an $\mathrm{R}$ of .614 . This analysis explained $38 \%$ of the variation in principals' perceived capacity for parent engagement.

Each model predicting principal capacity was statistically significant. However, the model predicting instructional leadership explained more variance than the models predicting school management and parental engagement.

Table 2.

Summary of Linear Regression Results Predicting Principal Capacity

\begin{tabular}{lllll}
\hline & $R$ & $R^{2}$ & $d f$ & $F(p)$ \\
\hline Capacity Score 1: School Management & .609 & .371 & 80 & $6.138(.000)$ \\
Capacity Score 2: Instructional Leadership & .670 & .449 & 80 & $8.497(.000)$ \\
Capacity Score 3: Parent Engagement & .614 & .377 & 80 & $6.309(.000)$ \\
\hline
\end{tabular}

Table 3 details the predictors of principal capacity for each of the three roles. Regression analyses indicate that the following are statistically significant $(p<.05)$ predictors of principal capacity for school management: principal EIS, job satisfaction, number of years as an educator, and number of years as a school principal. Among these factors, principal EIS and job satisfaction made the most significant contribution in predicting capacity for school management. Table 3 shows that principal EIS and job satisfaction were statistically significant predictors making the most significant contribution in predicting principal capacity for instructional leadership and parent engagement. 
Table 3.

Summary of Predictor Variables for Each Model

\begin{tabular}{|c|c|c|c|c|c|c|c|c|c|}
\hline \multirow[b]{2}{*}{ Predictor Variable } & \multicolumn{3}{|c|}{$\begin{array}{c}\text { Capacity Score } 1 \\
\text { (School Management) }\end{array}$} & \multicolumn{3}{|c|}{$\begin{array}{l}\text { Capacity Score } 2 \\
\text { (Instructional } \\
\text { Leadership) }\end{array}$} & \multicolumn{3}{|c|}{$\begin{array}{c}\text { Capacity Score } 3 \\
\text { (Parent Engagement) }\end{array}$} \\
\hline & Std. $\beta$ & $t$ & $p$ & Std. $\beta$ & $t$ & $p$ & Std. $\beta$ & $t$ & $p$ \\
\hline $\begin{array}{l}\text { Instructional } \\
\text { Supports (EIS) } \\
\text { Time on }\end{array}$ & .518 & 4.93 & .000 & .422 & 4.29 & .000 & .407 & 3.90 & .000 \\
\hline $\begin{array}{l}\text { Instructional } \\
\text { Leadership Tasks } \\
\text { (TILT) } \\
\% \text { of Disadvantaged }\end{array}$ & -.135 & $\begin{array}{l}- \\
1.26\end{array}$ & .212 & -.119 & -1.19 & .240 & -.055 & -.518 & .606 \\
\hline Students Served & -.173 & $\begin{array}{l}- \\
1.78\end{array}$ & .080 & .023 & .257 & .798 & -.054 & -.562 & .576 \\
\hline $\begin{array}{l}\text { Number of Years } \\
\text { Working as } \\
\text { Educator } \\
\text { Number of Years }\end{array}$ & -.267 & - & .030 & -.130 & -1.15 & .253 & .108 & .898 & .372 \\
\hline $\begin{array}{l}\text { Working as School } \\
\text { Principal }\end{array}$ & .239 & 2.32 & .023 & .134 & 1.40 & .167 & -.090 & -.875 & .385 \\
\hline $\begin{array}{l}\text { Principal } \\
\text { Effectiveness } \\
\text { Principal Job }\end{array}$ & -.051 & - & .605 & -.006 & -.063 & .950 & -.005 & -.047 & .962 \\
\hline Satisfaction & .482 & 4.26 & .000 & .661 & 6.25 & .000 & .413 & 3.67 & .000 \\
\hline
\end{tabular}

Results from linear regression analysis predicting EIS revealed that the extent to which principals perceive instructional supports to be effective is dependent upon their job satisfaction, how capable they think their teachers are in maintaining communication with parents, and the number of years they worked as an educator and a school principal. Job satisfaction and how principals rate the level of teachers' capacity to maintain communication with parents made the most significant contribution in predicting principal EIS. Results showed that $42 \%$ of the variation in principal EIS can be accounted for by the independent variables included in the regression. The results are reliable as detailed in Table 4.

Frequency data indicate that $51 \%$ of principals rated mentoring teachers as an instructional support with quite a bit of influence over student learning outcomes, followed by new teaching methods (47\%), learning aids (46\%), and classroom resources (42\%). A substantial number of principals rated community attention on student achievement $(49 \%)$ and city department of education involvement (47\%) as supports with some influence over student learning outcomes, followed by parent involvement in school (46\%) and feedback on classroom observations (46\%).

\section{Qualitative Results}

Principals shared that teaching is very similar to the way that it had been under Soviet rule. Student-centered learning is related to schools catering to the students' interests and talents (academic and otherwise) through extra-curricular activities outside the main curriculum, as well as paying attention to students' individual socio-emotional needs. The 
following comment illustrates the working definition for student-centered learning in Bishkek public schools.

We teach children the same way they taught us. How my teacher stood at the blackboard, so do I stand. As she counted the notebooks, so do I count. I do it completely unconsciously. But with this generation, it does not work that way. It has already come up with other ideas about how the world is organized. Here we have this struggle between what they demand and what we actually can give.

While discussing the inclusion of extra-curricular activities to foster student needs and talents, principals noted the issues they face with parents and their level of engagement in school.

Table 4.

Summary of Predictor Variables for Principal Effectiveness of Instructional Supports

\begin{tabular}{|c|c|c|c|c|}
\hline Independent Variable & Standardized $\beta$ & $t$ & $p$ & \\
\hline \# of years educator & .303 & 2.575 & & .012 \\
\hline \# of years principal & -.240 & -2.387 & & .020 \\
\hline Highest level of education & .137 & 1.329 & & .188 \\
\hline $\begin{array}{l}\text { Time on instructional leadership } \\
\text { Tasks }\end{array}$ & .111 & 1.015 & & .313 \\
\hline Principal effectiveness & -.038 & -.386 & & .700 \\
\hline Principal job satisfaction & -.341 & -2.873 & & .005 \\
\hline $\begin{array}{l}\text { Teachers make good use of basic } \\
\text { resources to teach students }\end{array}$ & -.038 & -.222 & & .825 \\
\hline $\begin{array}{l}\text { Teachers make good use of tech } \\
\text { resources to teach students }\end{array}$ & .181 & 1.339 & & .185 \\
\hline $\begin{array}{l}\text { I ask teachers for their opinions } \\
\text { about admin matters }\end{array}$ & .035 & .282 & & .779 \\
\hline $\begin{array}{l}\text { Teachers keep close contact with } \\
\text { parents in the community }\end{array}$ & .410 & 2.835 & & .006 \\
\hline Dependent Variable & $\boldsymbol{R}$ & $R^{2}$ & $d f$ & $F(p)$ \\
\hline EIS Score $(N=81)$ & .651 & .424 & 10 & $5.146(.001)$ \\
\hline
\end{tabular}

Principals voiced frustration with both the intensity of parental demands and the apathy of parental disengagement in their child's learning. Principals identified parents, together with their students, as customers that they need to serve. At the same time, principals made note that parents provide many classroom resources necessary to promote learning. The following comments below capture this sentiment.

The student will soon be a customer, not only parents. Parents now absolutely know exactly what they want. They want more. Therefore, they also choose the schools. That is, the parents want to get the product [on] their side. Teachers are ready and willing to give, but they need the appropriate resources because they cannot organize all this themselves. 
One principal noted that,

Now parents have become complicated with a certain mindset. They do not think it is needed to teach how to live in this world. Academic knowledge is needed, of course, but it is necessary to look in a new way. Teachers are facing difficulties because parents see only their own side. There are parents who understand that they should invest equally, as much as the school, and there are also those who shove the child into school and say, 'I do not have to do anything, everything must be done by the school.' And by and large, the school only directs. Parents do not know the program. Parents do not know the educational process. Parents do not understand that when there are 40 children in the class and hours are few,there is no time to work out the whole program. Parents are generally far from these things.

Another principal went on to say,

Parents want to be less worried. You give the child to school and this is your problem there at school. And when you call to come to school and call for cooperation, you say, 'We have to work together.' Parents answer, 'Our task is to shoe, to dress, to feed. I've sent you a child to school - teach!'

Principals discussed the emergence of elite schools demanded by parents to ensure that their children gain a greater degree of academic learning. The comments below show how parents hold Bishkek public schools accountable for their students and the pressures associated with it. A commonality among responses was that parents have a limited view of their role in their child's learning, which puts greater pressure on the school.

This struggle of parents for elite schools is scary. In general, smart parents know that it is necessary to lead a child not to the name of the school, but to a good, strong teacher. And such a teacher may be found in a simple school and be able to provide such a knowledge base that creates a child's sense of confidence, a sense of inner self-preservation, and forms with him a vital position at a high level.

Additionally,

At the request of our parents, since last year, we have opened paid educational services for primary classes, according to the curriculum. The English language is provided from the $3^{\text {rd }}$ grade. But some parents come and ask to open additional courses from 1st grade. And there are parents who believe that if this is a public free school, then we should only deal with the upbringing and education of children. I can even say that this is an inheritance from the Soviet Union. Even if something happens after the lessons with the child, they immediately say that the school is to blame. So, we wrote to the higher authorities so that they could consider the possibility of regulating the responsibility of parents who must also study at home and educate and raise children, because at school the children are five to six hours, and all the rest of the time they are at home, in the family. 
Principals noted that the school leadership training they received allowed them to improve their soft skills, particularly their listening skills, assertiveness, and confidence. Most of the training they received was offered through education development projects funded by international development agencies such as USAID, which addressed school management.

Principals discussed the following areas that still need to be addressed through further leadership training: communication and assertiveness skills; clerical, statistical, and decision-making skills; and pedagogical skills to improve student-centered learning. Principals stated that while teachers receive training on student-centered learning, principals do not. Principals indicated that their understanding of student-centered learning and instructional leadership concepts such as teacher supervision and mentorship were developed through training they received as a teacher. Some principals noted that they authored teacher training materials on "child-centric" approaches. Principals showed a preference for international experts to provide these trainings.

\section{Limitations}

Limitations of this study derive from the use of self-reported perceptions of principals and social desirability bias. Principals may have overestimated their sense of self-efficacy and outcome expectancy, and the presence of others during survey completion may have contributed to the tendency of respondents to reply in a manner that may be favorable to others. Internal and external validity of the study was limited by the translation of study concepts from English to Russian and Kyrgyz.

\section{Discussion}

Findings from the regression analyses were reliable enough to lead to conclusions about building a sense of capacity for each area of public-school leadership in Bishkek. In order to affect the sense of capacity for instructional leadership among Bishkek's publicschool principals, paying attention to their perception of the instructional supports at their disposal and their sense of job satisfaction is worthy. The model predicting instructional leadership capacity accounted for $45 \%$ of variation, which indicates that any changes in perception of instructional supports and job satisfaction are related to changes in their sense of capacity for instructional leadership. Sense of job satisfaction as a factor influencing selfefficacy aligns with findings by Sindhvad (2009).

Principal perception of instructional supports and job satisfaction deserves attention to better understand principal capacity for parental engagement as well. The same factors, along with principals' level of experience in teaching and school leadership, deserve attention in understanding capacity for school management. However, findings indicate that there are other factors to consider that this study did not include in terms of affecting the capacity for parental engagement and school management.

It is surprising that principals in this study rated their sense of capacity for instructional leadership as high as or slightly higher than for school management given that the literature indicates that instructional leadership is least likely to be realized upon decentralization. It was expected that the capacity for parental engagement would be high given the prevalence of informal parental payments. More work needs to done to better understand the nuances of this finding.

Findings from the regression analysis predicting principal perception of instructional supports are also reliable enough to conclude that principals' sense of job satisfaction, how capable they think their teachers are in maintaining communication with parents, and the 
level of experience as a teacher and school principal affect principal perception of instructional supports. Findings indicate that to affect a change in principals' perception of instruction supports, a change in job satisfaction and how principals rate the level of teacher capacity to maintain communication with parents especially deserves attention. The model predicting principals' perception of instructional supports accounted for $42 \%$ of the variation indicating that changes to these factors are related to changes in principals' perception of instructional supports.

The occurrence of principal perception of instructional supports as a predictor of each area of principal capacity was expected given that self-efficacy and outcome expectancy inform behavior. Bandura (1977) noted that self-efficacy and outcome expectancy are differentiated. A principal can believe that particular instructional supports will produce improved student outcomes, but if they have doubts about whether they can implement the instructional support, then their perception of effectiveness does not influence their action.

As discussed earlier, Bandura's (1997) theory of triadic reciprocal causation is the rationale explaining the relationship between principal self-efficacy and their performance, use of power, and coping strategies. Triadic reciprocal causation gives insight into the personal characteristics and behavioral and environmental factors at work in a leadership context. Findings from the interview data provide insight into key factors defining the context of public-school leadership in Bishkek, which set the stage for understanding the predictors likely to affect principal capacity and perception of instructional supports. The following sections focus on dynamics defining principals' job satisfaction and perception of instructional supports.

\section{Pressures from Parents and Elitization}

Interview data point to the fact that principals have a varied interpretation for student-centered learning, which resonates with findings by Prince-Rom and Sainazarov (2010) and De la Sablonniere (2009). Principals indicated that classroom teaching continues to follow methods established under Soviet rule. They equated student-centered learning to provision for extra-curricular activities enriching students' interests and talents outside of academic learning and attention to students' individual socio-emotional needs. Research identifies extra-curricular activities as an opportunity for bridging classroom learning to active, real-world learning with a positive impact on academic achievement (Metsapelto et al., 2012; Seow et al., 2014). Principals also discussed the emergence of elite schools that are demanded by parents to ensure their students gain more than academic learning through extra-curricular activities. Thus, it is assumed that principals are under pressure to meet the demands of parents to provide extra-curricular activities, which is a key feature of competition from elite schools.

The phenomena of elite schools revealed by principals in this study resonate with findings by Ramas (2016) on the role of informal parental payments in Bishkek, which were initially substituting insufficient state funding and are now associated with the commodification of education by promoting elitization of schools. As mentioned, Bishkek is an outlier following decentralization reforms as schools are financed by municipal taxes though considerably by parental contributions in the form of informal payments. Principal leadership in Bishkek is likely serving the dual mission and vision of school survival and elitization. Instructional leadership is likely to be in the context of providing extra-curricular activities and meeting students' socio-emotional needs as per parental demands. 


\section{Principal Job Satisfaction}

Principal sense of job satisfaction is a predictor for each area of principal capacity, which resonates with the literature. Job satisfaction is not only derived from how people perceive and feel about their jobs, but it is also related to their experiences with the job (Liu \& Bellibus 2018). Darmody and Smyth (2014) indicated that the breadth and complexity of school leadership tasks, along with significant cuts in government spending, add strain to the job of school principals in several education systems around the world. Maforah (2015) added that principals are sometimes experiencing role conflict while trying to live up to everyone's expectations. This role conflict reduces the principal's effectiveness. Also, external forces for improved learner outcomes and performance cause role strain, which can result in job dissatisfaction as principals try to strike a balance between instructional issues and empowering the teachers (Catona \& Stronger, 2007).

The largest sources of stress likely to affect a sense of job satisfaction among Bishkek public school principals are those associated with parental informal payments and pressures toward elitization. Success or failure of parent engagement is integral to sense of job satisfaction. Green et al. (2001) identified increased demands from parents as a factor of occupational stress among school principals, while Griffith (2001) found that principals who meet the needs of their schools were associated with greater parent involvement. Barr and Saltmarsh (2014) identified principals' attitudes, communication, and leadership as having an impact on parent engagement. Given that Bishkek public schools are heavily reliant on parental contributions to finance schools, capacity for parental engagement is foundational to overall school leadership. Lack of job satisfaction due to failed parent engagement affects capacity for school management and instructional leadership.

Interview data reveal a tension between two levels of parental engagement observed by the principals - demanding versus disengaged. Findings from Prince-Rom and Sainazarov (2010) resonant with the interview responses about disengaged parents in the sense that Kyrgyz parents in villages are not closely involved in the school's life and only think about better results their children achieve without attention to teaching methodologies in which the teachers are trained. It can be concluded that parents need to collaborate with teachers in educating their children. This area of parental engagement requires attention in Bishkek public schools. While a substantial proportion of principals in this study reported feeling satisfied in their jobs and rated themselves as having a great deal of influence over each of the responsibilities under parent engagement, further research is required to understand other aspects influencing the capacity for parent engagement which may influence other areas of school leadership.

\section{Perception of Instructional Supports}

The extent to which principals see a causal relationship between instructional supports and improved student outcomes is influenced by their sense of job satisfaction and their perception of teacher capacity to maintain communication with parents. As discussed, job satisfaction is likely to be influenced by pressures related to parent engagement. Since parent engagement is integral to school leadership in Bishkek, it is likely that principals experiences with instructional supports is dependent on their capacity for parent engagement. For example, parent involvement in school was rated as an instructional support with some influence over student learning. Principals may consider parent involvement in school if they believe that it is a tool to support student learning based on their experiences in parent engagement. 
Likewise, principals may consider instructional supports such as mentoring teachers, new teaching methods, learning aids, and classroom resources based on their perception of teacher capacity to maintain communication with parents. In essence, instructional supports aimed to influence student learning depends on teachers' ability for parent engagement. A principal is likely to provide classroom resources if he/she has experience in using them, and believes that teachers can engage with parents. Communicating with parents about school activities is part of the teacher's job. It is inferred that school leadership regarding parent engagement is distributed to teachers.

Liu and Bellibus (2018) observed that one important school factor that has not been fully examined in the literature is the dynamic relationship among the staff. Their study found a positive correlation between principals' perceived job satisfaction and their perception of staff mutual respect. Darmody and Smyth (2014) found that principals who were more likely to report feeling stressed also reported that teachers in their school were less open to new developments and challenges. Interview data indicate that principals are aware of teachers' workload, and they note their resistance to parental demands and their frustration over lack of parental engagement. Lack of partnership from teachers in parental engagement is likely to cause job stress for principals. Additionally, Silova (2009) suggested that it is the weakest students who are typically entering pre-service teacher education programs in Kyrgyzstan. General teacher capacity may compound any stress related to lack of parental engagement.

\section{Implications on School Leadership Training in Decentralized Contexts}

Bandura (2009) theorized that more than actual knowledge and skills, people's judgments of their capabilities drive them to achieve the goals they set for themselves. For that matter, as important as skills and knowledge are to principal success, self-efficacy is equally important. Tschannen-Moran and McMaster (2010) suggested that the process of influencing self-efficacy beliefs is not straightforward because self-efficacy is a motivational construct associated with the willingness to try new practices, persistence, and resilience in the face of setbacks. Contextual factors influence willingness. The authors signify authentic task-specific mastery experiences and individualized verbal persuasion in raising self-efficacy beliefs and supporting the implementation of new methods. They state that only in the real setting can one experience the true test of his / her capabilities.

Findings from this study provide some insight into the context within which Bishkek public school principals operate. A major contextual factor affecting school leadership is parental demand for elitization together with parent apathy for engagement in their children's learning. Findings also show that while principals do not receive training in parent engagement, years of experience as a principal working within the post-Soviet phenomenon of emerging parental engagement has contributed to their sense of leadership capacity. Formal training or professional development can leverage principals" experience in ensuring informal payments from parents, meeting their demands, and engaging teachers to support and manage parent engagement.

Interview data captured principals' training needs to include communication and assertiveness skills, clerical, statistical, and decision-making skills, and pedagogical skills to improve student-centered learning. Task-specific mastery experiences in parent engagement, instructional leadership, and school management are key to influencing principal capacity, together with their perception of instructional supports. Bishkek principals would benefit from training or professional development in approaches toward empowering teachers to support efforts towards parent engagement and manage parent relationships. 


\section{Conclusion}

The literature on decentralization of education and its effect on school leadership generally points to a lack of instructional leadership while characterizing it as being adaptable to unique school needs (Chapman 2000; Hallinger 2010). Public school principals in Bishkek who participated in this study reported feeling capable as an instructional leader. This is considered with some caution as findings from the study indicate that any sense of capacity for instructional leadership is likely limited to extra-curricular enrichment. School principals are unlikely to support student-centered classroom instruction because academic learning continues to follow the Soviet way of didactic instruction. Further research is required to understand instruction for extra-curricular enrichment as being student-centered, and how instructional leadership practices such as instructional supervision and mentoring teachers take effect in Bishkek public schools.

Municipal financing of public schools in Bishkek falls short, and informal payments from parents make up a substantial amount. These payments come with the demand for public schools to follow the emerging trend of elitization and offer extra-curricular enrichment to help realize students' potential outside of academics. School principals, together with their teachers, are challenged to meet this demand. Engagement with parents can influence principal job satisfaction, which in turn influences their sense of capacity for instructional leadership, school management, and parental engagement. While a substantial proportion of principals in this study reported feeling satisfied in their jobs and rated themselves as having a great deal of influence over each of the responsibilities under parent engagement, further research is required to understand other aspects influencing capacity for parent engagement which may influence other areas of school leadership.

Another factor influencing the sense of capacity for school leadership is how principals perceive instructional supports. Principals are likely to provide classroom resources and learning aids or employ teacher support strategies such as classroom observations and mentorship if they believe their teachers are capable of engaging parents. Parent engagement is a distributed leadership function. The working relationship with teachers is another source of job satisfaction for principals influencing their sense of capacity for school leadership.

Professional development in the country (and most others) often follows a one-sizefits-all approach that does not take into consideration contextual factors affecting principals' decision-making processes, particularly in terms of instructional leadership. By studying principals' sense of self-efficacy for key functions of instructional leadership, this study contributes to the literature of school leadership in post-Soviet countries by identifying key contextual factors that should be considered in the design of any training / professional development for school principals.

\section{References}

Akmatova, C. (2008). The effects of decentralization on the provision of public education service in the Kyrgyz Republic. Universiteit Maastricht - Maastricht Graduate School of Governance, The Netherlands.

Bakker, A. B. (2009). Building engagement in the workplace. In R. J. Burke \& C. L. Cooper (Eds.), The peak performing organization. Oxon, UK: Routledge.

Bandura, A. (1977). Self-efficacy: Toward a unifying theory of behavioral change. Psychological Review, 84, 191-215.

Chapman, D. W. (2000). Trends in educational administration in developing Asia. Educational Administration Quarterly, 36(2), 283-308. 
Chapman, D., \& Burchfield, S. (1994). How headmasters perceive their role: A case study in Botswana. International Review of Education, 4O(6), 401-419.

Cheema, J. R. (2013). Does it matter how you measure it? The case of self-efficacy in mathematics. Issues in Educational Research, 23(3).

De la Sablonniere, R., Taylor, D. M., \& Sadykova, N. (2009). Challenges of applying a studentcentered approach to learning in the context of education in Kyrgyzstan. International Journal of Educational Development, 29, 628-634.

DeJaeghere, J. G., Williams, R., \& Kyeyune, R. (2009). Ugandan secondary school headteachers' efficacy: What kind of training for whom? International Journal of Educational Development, 29, 312-320.

DeYoung, A. J., Reeves, M., \& Valyayeva, G. K. (2006). Surviving the transition: Case studies of schools and schooling in the Kyrgyz Republic since independence. Greenwich, CT: Information Age.

Federici, R. A., \& Skaalvik, E. M. (2011). Principal self-efficacy and work engagement: Assessing a Norwegian principal self-efficacy scale. Social Psychology Education, 14, 575-600.

Federici, R. A., \& Skaalvik, E. M. (2012). Principal self-efficacy: relations with burnout, job satisfaction and motivation to quit. Social Psychology Education, 15, 295-320.

Government of the Kyrgyz Republic (2012). Education Development Strategy for 2012-2020. Bishkek, Kyrgyz Republic: Author.

Hallinger, P. (2010). Developing instructional leadership. In B. Davies \& M. Brundrett (Eds.), Developing Successful Leadership (pp. 61-76). Dordrecht, Netherlands: Springer.

Hallinger, P., \& Heck, R. (1996). Reassessing the principal's role in school effectiveness: a review of empirical research, 1980-1995. Educational Administration Quarterly, 32(1), $5-44$.

Hallinger, P., Hosseingholizadeh, R., Hashemi, N., \& Kouhsari, M. (2018). Do beliefs make a difference? Exploring how principal self-efficacy and instructional leadership impact teacher efficacy and commitment in Iran. Educational Management Administration \&ळ Leadership, 46(5), 800-819.

Herczynski, J. (2002). Key issues of governance and finance of Kyrgyz education. Warsaw, Poland: Center for Social and Economic Research.

Kemmerer, F. (1990). An integrated approach to primary teacher incentives. In D. W. Chapman \& C. A. Carrier (Eds.), Improving educational quality. A global Perspective (pp. 135-152). Westport, CT: Greenwood Press.

Koren, A. (2007). Improving school leadership: Country background report for Slovenia. Retrieved from https://www.oecd.org/slovenia/38561414.pdf

Koren, A., \& Logaj, V. (2007). Ko učitelj postane ravnatelj: Raziskava o novoimenovanih ravnateljih. Šlsko polje, 18(5/6), 17-36.

Liu, Y., \& Bellibus, M. S. (2018). School factors that are related to school principals' job satisfaction and organizational commitment. International Journal of Educational Research, 90, 1-19.

Magno, C. (2009). Reimagining the school leadership paradigm in postsocialist context. European Education, 41(3), 23-41.

McCormick, M. J. (2001). Self-efficacy and leadership effectiveness: Applying social cognitive theory to leadership. Journal of Leadership Studies, 8(1), 22-33. 
McLean, G., \& Karimov, M. (2004). The role of human resource development in improving K-12 educational leadership in Kyrgyzstan. KEDI Journal of Educational Policy, 1(1), 99-118.

Mertaugh, M. (2004). Education in Central Asia, with particular reference to the Kyrgyz Republic in The Challenges of Education in Central Asia. In S. P. Heyneman \& A. J. De Young (Eds.), The Challenges of Education in Central Asia (pp. 2-26). Greenwich, CT: Information Age

Open Society Institute (2002). Education development in Kyrgyzstan, Tajikistan and Uzbekistan: Challenges and ways forward. Budapest, Hungary: Author.

Prince-Rom, A., \& Sainazarov, K. (2010). Active-learning pedagogies as a reform initiative: The case of Kyrgyzstan. Washington, DC: US Agency for International Development.

Rupar, B. (2008). Kako so ravnatelji sol v projektu Didakticna prenova gimnazij vodili in spodbujali vpeljevanje sprememb? (How did principals of the schools included in the Didactic Reform Project lead and encourage the implementation of change?). $V$ zgoja in izobraževanje, 39(3), 55-59.

Sentocnik, S., \& Rupar, B. (2009). School leadership of the future: How the National Education Institute in Slovenia supported schools to develop distributed leadership practice. European Education, 41(3). 7-22.

Sentočnik, S., Sales, G. C., \& Richardson, J. W. (2018). Education reform in Georgia: Recommendations for building leadership capacity as a critical success factor for instructional change. International Journal of Leadership in Education, 21(6),651-668. doi: $10.1080 / 13603124.2016 .1224931$

Silova, I. (2009). The crisis of the post-soviet teaching profession in the Caucasus and Central Asia. Research in Comparative and International Education, 4(4), 334-355.

Sindhvad, S. (2009). School principals as instructional leaders: an investigation of school leadership capacity in the Philippines (Doctoral dissertation, University of Minnesota). Retrieved from http://hdl.handle.net/11299/56986.

Szymendera, M. (2013). The relationship between self-efficacy, school and personal characteristics, and principal behaviors related to affecting student achievement (Doctoral dissertation, Leigh University). Retrieved from https:// preserve.lehigh.edu/cgi/viewcontent.cgi? article=2646\&context=etd.

Tschannen-Moran, M., \& McMaster, P. (2010). Sources of self-efficacy: Four professional development formats and their relationship to self-efficacy and implementation of a new teaching strategy. The Elementary School Journal, $110(2), 228-245$.

Usher, E. L. (2009). Sources of middle school students' self-efficacy in mathematics: A qualitative investigation. American Educational Research Journal, 46(1), 275-314.

Usher, E. L., \& Pajares, F. (2008). Sources of self-efficacy in school: Critical review of the literature and future directions. Review a/Educational Research, 78(4), 751-796.

Versland, T. M. (2016). Exploring self-efficacy in education leadership programs: What makes the difference? Journal of Research on Leadership Education, 11(3), 298-320.

Yakavets, N. (2016) Societal culture and the changing role of school principals in the postSoviet era: The case of Kazakhstan. Journal of Educational Administration, 54(6), 683702.

Yakavets, N. (2017). Negotiating the principals and practice of school leadership: The Kazakhstan experience. Educational Management Administration and Leadership, 45(3), 445-465. 


\section{About the Authors}

Swetal Sindhvad is former Education Specialist for Asian Development Bank (ADB). During her tenure at $\mathrm{ADB}$, she led the development, management and evaluation of sovereign lending projects in the education and training sector for governments in Southeast Asia. Currently, she is founding Executive Director of i3Development leading education research and capacity development initiatives in emerging economies of Asia. Her research focuses on educational governance, school management and public private partnerships in education. She also serves as Adjunct Professor at Drexel University where she has taught courses in education policy analysis and comparative higher education.

Jayson $W$. Richardson is an associate professor in the Department of Educational Leadership Studies at the University of Kentucky. His 50-plus peer-reviewed publications focus on technology leadership, international development, and educational reform. He is currently researching 30 future-ready schools around the world to understand leadership, innovation, and deeper learning.

Alexandr Ivanov is the Director of the Foundation for Educational Initiatives Support (FEIS) in Kyrgyzstan. He is responsible for the management of planning and implementing school reforms in all regions of the country, as well as conducting systematic strategic research for the Ministry of Education. His work integrates into international professional and research networks, such as Network of Educational Policy Centers (NEPC, Croatia) and International Step by Step Association (ISSA, Netherlands). Previously, Alexandr coordinated educational projects at the Kyrgyz branch of the Soros Foundation. Alexandr's research interests are related to school management, teacher training policies and curriculum reform.

John Eric M. Lingat is a doctoral candidate in Educational Psychology at the University of Kentucky. He previously served as an Assistant Principal at a dual-language public school. His research interests include measurement, assessment, and evaluation related to cognition, performance, and achievement in a variety of learning environments. He holds an MEd in Curriculum \& Instruction, focusing on Education Policy, from American University in Washington, DC. John Eric has taught education courses in psychology, policy, and instruction. 